\title{
Políticas Editoriais
}

\section{Foro e escopo}

Extensão Universitária e relações entre Universidade e outros setores da sociedade, em especial nos países da América Latina. Recebe trabalhos que tratem exclusivamente sobre Extensão Universitária.

\section{Processo de avaliação pelos pares}

Avaliação duplo cega.

\section{Periodicidade}

Semestral.

\section{Política de Acesso Livre}

Esta revista oferece acesso livre imediato ao seu conteúdo, seguindo o princípio de que disponibilizar gratuitamente o conhecimento científico ao público proporciona maior democratização mundial do conhecimento.

\section{Experiência - Revista Científica de Extensão Universidade Federal de Santa Maria | Brasil http://www.ufsm.br/experiencia E-mail: experienciaufsm@gmail.com ISSN 2447-1151}

Este trabalho está licenciado sob uma Licença Creative Commons Attribution 3.0 